Arif G. Huseynov,

Dr.Sc., Azerbaijan State Oil and Industry University, Azerbaijan

ORCID ID, 0000-0003-0504-745X

email: arif.huseynov@asoiu.edu.az

\title{
IMPACT OF ENVIRONMENTAL INNOVATION ON COUNTRY SOCIO-ECONOMIC DEVELOPMENT
}

Abstract. Global warming and deterioration of the ecological situation trigger the necessity of innovation development and implementation to reduce the negative impact of industry on the environment. It is considered that the oil industry is one of the most environmentally damaging industries. Therefore, the implementation of environmental innovation in the oil industry becomes crucial. This paper is dedicated to identifying environmental innovation impact on country socio-economic development parameters in countries specialized in oil extraction and production. The article realized a bibliometric analysis with VOSviewer v.1.6.16 to identify critical contextual directions of scientific research on environmental innovation. In the paper, it is developed and tested a scientific hypothesis about the positive influence of environmental innovation on country socio-economic development (CO2 emissions from manufacturing industries and construction, electricity production from oil sources, employment in industry, and industry value added are chosen as proxies of environmental innovation, while GDP growth, current account balance, foreign direct investment and gross fixed capital formation - as proxies of country socio-economic development). Under testing of the research hypothesis, it is realized several procedures: 1) correlation analysis aimed at identification of strongly correlated explanatory variables and their elimination to avoid multicollinearity problem; 2) comprehensive analysis of descriptive statistics aimed at identification of data sufficiency; 3) identification of model specification with Hausman test (random or fixed effects model); 4) regression modeling and characteristics of its results (in this research, it is developed four regression models with different dependent variables). Technically all these procedures are realized in Stata 12/SE software. Research is realized based on data for 9 countries specializing in oil extraction and production, such as Azerbaijan, Canada, Brazil, the Russian Federation, Saudi Arabia, Oman, Romania, the Republic of Yemen, and the Islamic Republic of Iran. The time horizon is 2005-2019 (or the available last year). Bibliometric and panel data regression analysis allows concluding that oil-producing countries' environmental innovation improves oil enterprises' competitiveness and stimulates socio-economic growth in these countries.

Keywords: environmental innovation, socio-economic development, oil industry, panel data analysis.

Introduction. The oil and gas industry is facing increasing demands to clarify the implications of energy transitions for their operations and business models and to explain the contributions that they can make to reducing greenhouse gas (GHG) emissions and achieving Sustainable Development Goals (IEA, 2021). There is a challenge for oil industry enterprises in modern conditions: they might combine their commercial interests to eliminate their negative impact on the environment. Therefore, one of the possible ways to balance two targets mentioned above is implementing environmental innovation to improve oil extraction and production technologies. Otherwise, the oil industry would be damaged. According to Global Energy Review (IEA, 2020), oil demand could drop by 9\%, returning oil consumption to 2012 levels. Thus, environmental innovation in the oil industry might improve its productivity and efficiency and decrease its negative environmental influence. Moreover, the oil industry continues to ensure high return rates, but the renewable energy industry also demonstrates considerable annual growth that might lead to stagnation in the oil industry. Therefore, analyzing environmental innovation's role in ensuring socio-economic development in countries specializing in oil extraction and production becomes very urgent.

Literature Review. Analysis of publication on environmental innovation and its impact on country socio-economic indicators reveals numerous publications on general environmental issues. Still, there is a lack of publications on implementing environmental innovation in different industries (specifically, in the oil industry). In this research, the bibliometric analysis covers 871 publications in Scopus for 1988-2020

Cite as: Huseynov, A. G. (2021). Impact of Environmental Innovation on Country Socio-Economic Development. Marketing and Management of Innovations, 2, 293-302. http://doi.org/10.21272/mmi.2021.2-24 
dedicated to environmental innovation. Only 9 of them are aimed at research of environmental innovation in the oil industry. In terms of clarifying the role of environmental innovation on country socio-economic development, it should be valuable to point out and characterize the most cited publication in this field for 1988-2020 (Table 1).

Table 1. 10 most cited Scopus publication on environmental innovation for the period 1988-2020

\begin{tabular}{|c|c|c|c|c|c|}
\hline № & Publication title & Authors & Year & Source & $\begin{array}{c}\text { Number of } \\
\text { citations }\end{array}$ \\
\hline 1 & $\begin{array}{c}\text { Understanding environmental influences } \\
\text { on walking: Review and research } \\
\text { agenda }\end{array}$ & $\begin{array}{l}\text { Owen, N., } \\
\text { Humpel, N., } \\
\text { Leslie, E., } \\
\text { Bauman, A., } \\
\text { Sallis, J.F. }\end{array}$ & 2004 & $\begin{array}{l}\text { American Journal } \\
\text { of Preventive } \\
\text { Medicine } \\
\text { 27(1), pp. 67-76 }\end{array}$ & 895 \\
\hline 2 & $\begin{array}{l}\text { Determinants of environmental } \\
\text { innovation-New evidence from German } \\
\text { panel data sources }\end{array}$ & Horbach, J. & 2008 & $\begin{array}{l}\text { Research Policy } \\
\text { 37(1), pp. 163-173 }\end{array}$ & 677 \\
\hline 3 & $\begin{array}{l}\text { Determinants of environmental } \\
\text { innovation in US manufacturing } \\
\text { industries }\end{array}$ & $\begin{array}{l}\text { Brunnermeier, S.B., } \\
\text { Cohen, M.A. }\end{array}$ & 2003 & $\begin{array}{l}\text { Journal of } \\
\text { Environmental } \\
\text { Economics and } \\
\text { Management } \\
\text { 45(2), pp. 278-293 }\end{array}$ & 630 \\
\hline 4 & $\begin{array}{l}\text { Environmental innovation and R\&D } \\
\text { cooperation: Empirical evidence from } \\
\text { Spanish manufacturing firms }\end{array}$ & De Marchi, V. & 2012 & $\begin{array}{l}\text { Research Policy } \\
\text { 41(3), pp. 614-623 }\end{array}$ & 488 \\
\hline 5 & $\begin{array}{l}\text { Suppliers and environmental innovation } \\
\text { the automotive paint process }\end{array}$ & $\begin{array}{l}\text { Geffen, C.A., } \\
\text { Rothenberg, S. }\end{array}$ & 2000 & $\begin{array}{l}\text { International } \\
\text { Journal of } \\
\text { Operations and } \\
\text { Production } \\
\text { Management } \\
\text { 20(2), pp. 166-186 }\end{array}$ & 420 \\
\hline 6 & $\begin{array}{l}\text { Innovation and the international } \\
\text { diffusion of environmentally responsive } \\
\text { technology }\end{array}$ & $\begin{array}{l}\text { Lanjouw, J.O., } \\
\text { Mody, A. }\end{array}$ & 1996 & $\begin{array}{l}\text { Research Policy } \\
\text { 25(4), pp. 549-571 }\end{array}$ & 417 \\
\hline 7 & $\begin{array}{l}\text { Necessity as the mother of 'green' } \\
\text { inventions: Institutional pressures and } \\
\text { environmental innovation }\end{array}$ & $\begin{array}{l}\text { Berrone, P., } \\
\text { Fosfuri, A., } \\
\text { Gelabert, L., } \\
\text { Gomez-Mejia, L.R. }\end{array}$ & 2013 & $\begin{array}{l}\text { Strategic } \\
\text { Management } \\
\text { Journal } \\
\text { 34(8), pp. } 891-909\end{array}$ & 368 \\
\hline 8 & Environmental supply chain dynamics & Hall, J. & 2000 & $\begin{array}{l}\text { Journal of Cleaner } \\
\text { Production } \\
\text { 8(6), pp. } 455-471\end{array}$ & 358 \\
\hline 9 & $\begin{array}{l}\text { The influence of different characteristics } \\
\text { of the EU environmental management } \\
\text { and auditing scheme on technical, } \\
\text { environmental innovation, and } \\
\text { economic performance }\end{array}$ & $\begin{array}{l}\text { Rennings, K., } \\
\text { Ziegler, A., } \\
\text { Ankele, K., } \\
\text { Hoffmann, E. }\end{array}$ & 2006 & $\begin{array}{l}\text { Ecological } \\
\text { Economics } \\
57(1), \text { pp. } 45-59\end{array}$ & 315 \\
\hline 10 & $\begin{array}{c}\text { Conversion to organic farming: A typical } \\
\text { example of the diffusion of an } \\
\text { innovation? }\end{array}$ & Padel, S. & 2001 & $\begin{array}{l}\text { Sociologia Ruralis } \\
41(1) \text {, pp. } 40-61\end{array}$ & 314 \\
\hline
\end{tabular}

Sources: developed by the author based on (Scopus, 2021). 
Therefore, it is possible to conclude that the domain of the most cited Scopus publications aimed to research the impact of environmental technologies in manufacturing industries.

While the first publication in the list of most cited Scopus articles concerns mostly medical but not environmental issues, and the fifth publication is dedicated to some technical aspects in the automobile industry, it should be valuable to analyze those items from the closely connected list the research topic.

Horbach (2008) underlined that environmental innovation depends on numerous external and internal factors. Still, the most influential ones are technological transformation and R\&D investment, the transformation of corporate managerial technologies, national environmental regulation, and the adoption of ecological standards. Brunnermeier and Cohen (2003) pointed out that «environmental innovation (as measured by the number of successful environmental patent applications granted to the industry) responded to increases in pollution abatement expenditures. However, increased monitoring and enforcement activities related to existing regulations did not provide any additional incentive to innovate».

De Marchi (2012) mentioned that innovation in manufacturing industries leads to expansion of external cooperation on these issues (involvement of environmentally responsible suppliers, request for research from universities, etc.). Lanjouw and Mody (1996) studied the environmental innovations through the intensity of patenting activity and scale of pollution abatement expenditures. Researchers revealed that from 1970 to 1980 amount of patents on environmental innovation demonstrated considerable growth. They also pointed out that such a tendency is dominantly triggered by environmental regulation and ecological standards. Berrone et al. (2013) also mentioned that environmental innovation is driven by regulatory pressure. This effect is highly notable for those enterprises that provide more pollution than average in the industry. However, Kemp and Pearson (2007) mentioned that eco-innovation might be measured through R\&D expenditures, patent applicants, number of innovations, descriptions of individual innovations, data on sales of new products, changes in efficiency, and productivity. Hall (2000) mentioned that environmental innovation might be disseminated from customer company to supplier company.

Rennings et al. (2006) revealed that the maturity of environmental management systems and the creation of the R\&D department positively impact environmental process innovations. In contrast, improvement of the learning process has a positive influence on environmental product innovation. Besides authors concluded that the implementation of environmental management systems positively affected business economic and environmental performance. Padel (2001) mentioned that at the germinal stage, organic farming is used to be considered as environmental innovation. Still, nowadays, this agriculture perspective has become more and more popular and is displaced by another type of environmental innovation. Cainelli et al. (2012) pointed out that expansion of eco-innovation depends on numerous external and internal factors. Among the most important internal factors that influence environmental innovation is cooperation with national universities and research organizations. Moreover, the most effective types of environmental innovation that allow manufacturing companies to become more competitive are the limitation of $\mathrm{CO} 2$ emission and ISO labeling. Karintseva and Benetyte (2018) realized empirical research and proved that quality of governance influences environmental innovation and performance. He (2019) empirically proved (based on panel data regression analysis) that environmental innovation and sustainability are developed through trade liberalization and highlight that the scale of such an impact depends on country-driven factors. Mishenin et al. (2020) introduced that environmental innovation in waste management might be highly increased by creating cluster structures. In contrast, El Amri et al. (2020) declared that environmental innovation is affected by emission trading schemes. Donlagic and Moskalenko (2020) pointed out that restricting environmental regulation in EU countries stimulates foreign direct investment and stimulates environmental innovation. Taliento and Netti (2020) highlighted that environmental modernization and responsibility positively influence corporate brand and business performance. Under consideration of research results on environmental innovation analysis, it might be pointed out several common conclusions of authors: 
- environmental innovation has increasing importance in the manufacturing industry;

- the environmental innovation intensity is highly dependent on regulatory interventions in this sphere;

- number of patents and pollution abatement expenditures are commonly considered measurement indicators of environmental innovation;

- environmental innovation more than other types of innovation stimulates external cooperation;

- environmental innovation mostly aimed at anti-pollution measures.

Therefore, the literature review indicates that such indicators as $\mathrm{CO} 2$ emissions from manufacturing industries and construction, patents applications, R\&D expenditures, value-added are often chosen as proxies of environmental innovation. Nevertheless, there is a lack of researches aimed at clarification of influence of environmental innovation (especially in the oil industry) on country socio-economic indicators. All this proves the necessity to deepening research in this direction.

Methodology and research methods. This research aimed to determine environmental innovation impact on country socio-economic development parameters in countries specialized in oil extraction and production. To fulfill this task, it is proposed to realize two blocks of analysis: bibliometric and empirical (based on correlation and regression modeling). Under the bibliometric analysis, it might be identified key contextual directions of scientific research on environmental innovation importance with VOSviewer v.1.6.16 based on the most cited publications in the Scopus database on the relevant topic. As a key concept of bibliometric analysis, it should be noted that it is chosen «environmental innovation».

In turn, the empirical block of the research aims to test the hypothesis about the influence of proxies of environmental innovation in the oil industry on indicators of country socio-economic development. It should be noted that there is a lack of relative public data for a sufficient period that might be used to assess the environmental responsibility and efficiency of oil industry enterprises. Thus, in this research, it is considered to measure progress in implementing environmental innovation indirectly. Consequently, environmental innovation in the oil industry aims to reduce the negative impact of oil extraction and production on the environment and increase productivity. Therefore, it is proposed to use such indicators to assess the efficiency of environmental innovation implementation at oil extraction and production companies:

- CO2 emissions from manufacturing industries and construction (\% of total fuel combustion);

- Electricity production from oil sources (\% of total);

- Employment in industry (\% of total employment) (modeled ILO estimate);

- Industry (including construction), value added (\% of GDP).

Because in most empirical researches it is used to measure country socio-economic development through GDP growth rate dynamics, the sufficiency of current account balance, the intensity of capital formation, and foreign investments inflow, it is realized to use as dependent variables as follows:

- Current account balance (\% of GDP);

- Foreign direct investment, net (BoP, current US\$);

- GDP growth (annual \%);

- Gross fixed capital formation (\% of GDP).

It should be noted that four regression models would be built with the above-mentioned dependent variables (one model for each curtain variable). Moreover, it is also included several control variables in each model. Specifically, to highlight the innovation-oriented perspective of the research, it is added such variables as:

- Patent applications, nonresidents;

- Patent applications, residents;

- Research and development expenditure (\% of GDP). 
All variables are collected from the World Bank DataBank (World Development Indicators collection).

The country sample consists of 9 countries specializing in oil extraction and production, such as Azerbaijan, Canada, Brazil, the Russian Federation, Saudi Arabia, Oman, Romania, the Republic of Yemen, and the Islamic Republic of Iran. Time horizon - 2005-2019 (or available last year).

Under testing of the research hypothesis it is realized several procedures:

1) correlation analysis aimed at identification of strongly correlated explanatory variables and their elimination to avoid multicollinearity problem;

2) comprehensive analysis of descriptive statistics aimed at identification of data sufficiency;

3) identification of model specification with Hausman test (random or fixed effects model);

4) regression modeling and characteristics of its results (in this research, four regression models with different dependent variables are developed).

Results. Thus, to identify key contextual directions of scientific research on environmental innovation importance, it is realized a bibliometric analysis with VOSviewer v.1.6.16 (Figure 1).

Sosviewer

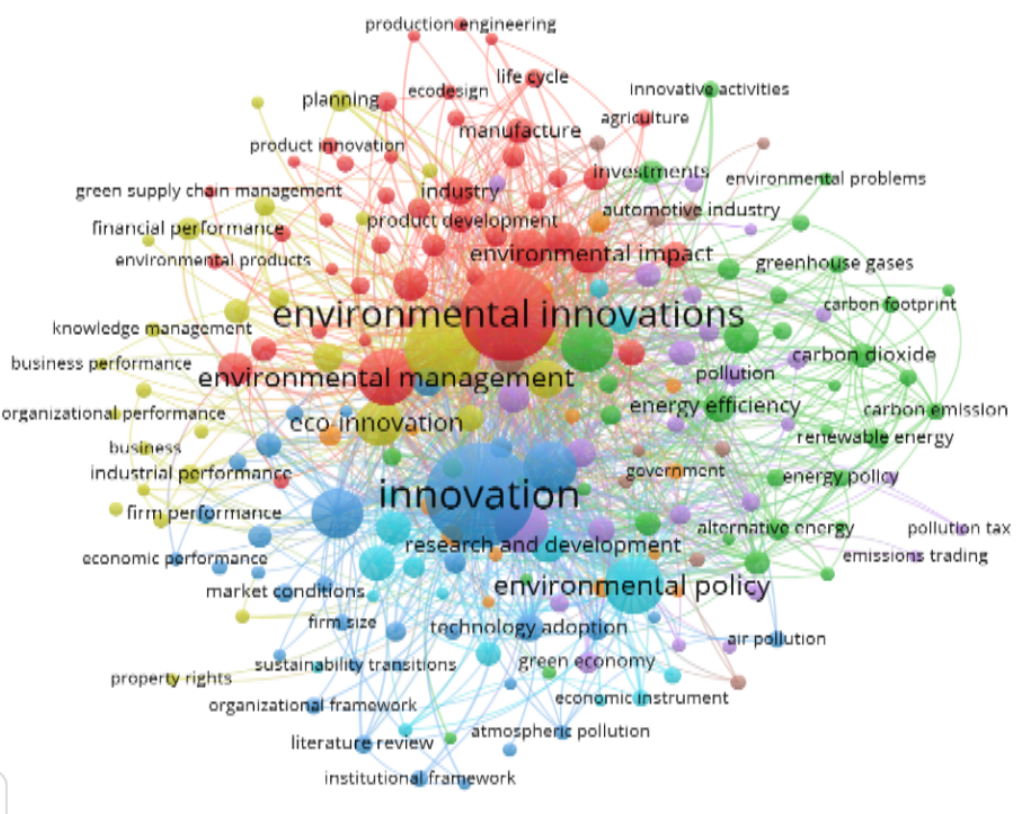

Figure 1. Results of bibliometric analysis based on Scopus publications in 1988-2020 Sources: developed by the author based on (Scopus, 2021).

Figure 1 shows 7 conceptual clusters on environmental innovation.

Under the bibliometric analysis, it is revealed that environmental innovation is closely connected with such issues as:

1) business strategic development and country sustainable development issues (red cluster);

2) energy efficiency, renewable energy and anti-pollution issues (green cluster);

3) innovative and environmentally-friendly managerial technologies (dark blue cluster);

4) patenting and knowledge-based approach (yellow cluster);

5) recycling issues (light blue cluster);

6) energy use issues (orange cluster); 
7) environmental expenditures and emission trading (violet cluster).

Thus, a strong correlation could be summarized between implementing environmental innovation and sustainable country development and business units' strategical development. Moreover, environmental innovation mostly aimed to reduce environmental pollution by expanding recycling technologies and transforming the energy production sector (optimization of energy usage and shifting from traditional sources of energy production to renewable ones). One more crucially important perspective of scientific interest in environmental innovation is patenting and knowledge-based approach and transformation of corporate management system on the environmentally-based background. Therefore, the bibliometric analysis results strongly support the choice of indicators such as $\mathrm{CO} 2$ emissions from manufacturing industries and construction, electricity production from oil sources, employment in industry, and industry value added as indirect proxies of environmental innovation expansion and efficiency. After bibliometric analysis on environment innovation, the empirical block of the research followed. It started with running a correlation analysis to eliminate multicollinearity between independent and control variables. Table 2 shows the correlation matrix.

Table 2. Correlation matrix of control variables

\begin{tabular}{|c|c|c|c|c|c|c|c|c|c|c|c|}
\hline Variables & $\mathrm{CO} 2$ & CAB & El_oil & Empl & FDI & GDPg & GFCF & IVA & Pat_nr & Pat_res & RD_exp \\
\hline $\mathrm{CO} 2$ & 1.000 & & & & & & & & & & \\
\hline$\overline{C A B}$ & -0.336 & 1.000 & & & & & & & & & \\
\hline El_oil & 0.265 & 0.503 & 1.000 & & & & & & & & \\
\hline Empl & 0.499 & -0.558 & -0.249 & 1.000 & & & & & & & \\
\hline FDI & -0.316 & 0.061 & -0.125 & 0.025 & 1.000 & & & & & & \\
\hline GDPg & -0.179 & 0.285 & 0.299 & -0.254 & 0.032 & 1.000 & & & & & \\
\hline GFCF & 0.056 & -0.319 & 0.138 & 0.144 & 0.257 & 0.320 & 1.000 & & & & \\
\hline IVA & 0.092 & 0.647 & 0.642 & -0.328 & 0.184 & 0.342 & 0.307 & 1.000 & & & \\
\hline Pat_nr & -0.183 & -0.305 & -0.377 & -0.096 & -0.097 & -0.209 & -0.330 & -0.724 & 1.000 & & \\
\hline Pat_res & -0.304 & -0.015 & -0.314 & 0.346 & 0.150 & -0.113 & -0.273 & -0.395 & 0.288 & 1.000 & \\
\hline RD_exp & -0.089 & -0.323 & -0.231 & 0.062 & 0.030 & -0.245 & -0.265 & -0.662 & 0.849 & 0.306 & 1.000 \\
\hline
\end{tabular}

Notes: $\mathrm{CO} 2$ - CO2 emissions from manufacturing industries and construction (\% of total fuel combustion); CAB - current account balance (\% of GDP); El_oil - Electricity production from oil sources (\% of total); Empl - Employment in industry (\% of total employment) (modeled ILO estimate); FDI - foreign direct investment, net (BoP, current US\$); GDPg - GDP growth (annual \%); GFCF - gross fixed capital formation (\% of GDP); IVA - Industry (including construction), value added (\% of GDP); Pat_res - Patent applications, residents; Pat_nr - Patent applications, nonresidents; RD_exp - Research and development expenditure (\% of GDP).

Sources: developed by the author using Stata 12/SE.

There is multicollinearity between some variables (cells with significant correlation are shadowed). Consequently, such variables as current account balance and electricity production from oil sources, employment in the industry might not be used as explanatory variables in the same model. Moreover, industry value added should not appear in models with such independent variables as current account balance, electricity production from oil sources, patents application from nonresident, research, and development expenditure. Thus, to avoid the harmful influence of multicollinearity on the quality of regression modeling, it is needed to eliminate the set of explanatory variables one of the strongly correlated indicators described above. Considering that the variable «industry value-added» has a strong correlation in most cases, it might be eliminated from the independent variables set. It is also needed to choose whether to eliminate patents application from nonresident or research and development expenditure: calculation of average correlation coefficient allow underlining that for the first variable it is equal to 0.1184 , while for the second -0.0568 . Therefore, the variable «patents application from nonresident» 
should be eliminated. The next stage of the research is the general characteristics of the descriptive statistics (Table 3).

Table 3. Descriptive statistics

\begin{tabular}{lccccc}
\hline Variable & Observation & Mean & Standard Deviation & Min & Max \\
\hline CO2 & 135 & 18.113 & 8.647 & 5.51 & 45.84 \\
CAB & 120 & 2.688 & 10.357 & -19.15 & 33.68 \\
El_oil & 135 & 15.508 & 23.718 & 0.08 & 100 \\
Empl & 135 & 23.757 & 6.818 & 10.18 & 36.88 \\
FDI & 117 & $-6.69 \cdot 10^{9}$ & $2.30 \cdot 10^{10}$ & $-9.05 \cdot 10^{10}$ & $5.28 \mathrm{e} \cdot 10^{10}$ \\
GDPg & 135 & 2.963 & 6.229 & -27.99 & 34.47 \\
GFCF & 120 & 23.514 & 4.321 & 14.56 & 41.31 \\
IVA & 135 & 41.185 & 14.589 & 17.92 & 71.5 \\
Pat_nr & 125 & 8279.441 & 11727.53 & 6 & 37028 \\
Pat_res & 125 & 5894.561 & 8538.645 & 1.5 & 29269 \\
RD_exp & 113 & 0.799 & 0.574 & 0.04 & 1.98 \\
\hline
\end{tabular}

Notes: CO2 - CO2 emissions from manufacturing industries and construction (\% of total fuel combustion); CAB - current account balance (\% of GDP); El_oil - Electricity production from oil sources (\% of total); Empl - Employment in industry (\% of total employment) (modeled ILO estimate); FDI - foreign direct investment, net (BoP, current US\$); GDPg - GDP growth (annual \%); GFCF - gross fixed capital formation (\% of GDP); IVA - Industry (including construction), value added (\% of GDP); Pat_res - Patent applications, residents; Pat_nr - Patent applications, nonresidents; RD_exp - Research and development expenditure (\% of GDP).

Sources: developed by the author using Stata 12/SE.

Based on the data from Table 3, it could be pointed out that there are some omitted observations. However, the panel is still considered strongly balanced. Consequently, the omission of variables does not influence the adequacy and quality of the model. The next procedure is aimed at clarification of panel regression model specification with the Hausman test. Running of the Hausman test allows identifying that fixed effects panel regression model fits data better. Moreover, it might be concluded that environmental innovation's formalization impact on country socio-economic development factors may affect or bias the predictor or outcome variables. There is a necessity to control for this. The next stage of the research is panel data regression analysis. Results of the regression analysis are presented in Tables 4-7.

Table 4. Results of the identification of environmental innovation measures impact on GDP growth in 9 countries in 2005-2019 (fixed effects model specification)

\begin{tabular}{|c|c|c|c|c|c|c|c|}
\hline GDPg & Coefficients & Standard Error & t-value & p-value & $95 \%$ Confidence & Interval & Sig \\
\hline $\mathrm{CO} 2$ & 0.137 & 0.296 & 0.46 & 0.646 & -0.452 & 0.725 & \\
\hline El_oil & 0.811 & 0.127 & 6.37 & 0.000 & 0.559 & 1.064 & *** \\
\hline Empl & 0.154 & 0.540 & 0.29 & 0.775 & -0.917 & 1.226 & \\
\hline Pat_res & 0.000 & 0.000 & -0.50 & 0.620 & -0.001 & 0.000 & \\
\hline RD_exp & 4.448 & 2.305 & 1.93 & 0.057 & -0.127 & 9.024 & * \\
\hline Constant & -12.576 & 11.847 & -1.06 & 0.291 & -36.091 & 10.939 & \\
\hline
\end{tabular}

Notes: ${ }^{* * *}$ - significance at $1 \%$ level, ${ }^{* *}$ - significance at $5 \%$ level, ${ }^{*}$ - significance at $10 \%$ level.

Sources: developed by the author using Stata 12/SE.

In terms of identifying environmental innovation measure impact on GDP growth, it can be concluded that only two variables have a statistically significant influence on dependent variables. Specifically, an increase in $1 \%$ of electricity production from oil sources boosts GDP growth by $0.811 \%$, while the increase of the share of R\&D expenditures by $1 \%$ leads to an increase of GDP growth rate of $4.45 \%$.

The independent variable influences the current account balance: the increase of the share of R\&D expenditures by $1 \%$ leads to a decrease in the current account balance of $9.872 \%$. The same independent 
variable also influences net foreign direct investment: an increase in $1 \%$ of the share of R\&D expenditures increases net foreign direct investment by $15.4 \cdot 10^{9}$ USD.

Table 5. Results of the identification of environmental innovation measures impact on the current account balance in 9 countries in 2005-2019 (fixed effects model specification)

\begin{tabular}{|c|c|c|c|c|c|c|c|}
\hline$\overline{\mathrm{CAB}}$ & Coefficients & Standard Error & t-value & p-value & 95\% Confidence & Interval & Sig \\
\hline$\overline{\mathrm{CO} 2}$ & 0.002 & 0.436 & 0.01 & 0.996 & -0.866 & 0.871 & \\
\hline El_oil & -0.040 & 0.198 & -0.20 & 0.841 & -0.433 & 0.354 & \\
\hline Empl & -0.839 & 0.827 & -1.01 & 0.314 & -2.485 & 0.807 & \\
\hline Pat_res & 0.000 & 0.001 & 0.26 & 0.797 & -0.001 & 0.002 & \\
\hline RD_exp & -9.872 & 3.464 & -2.85 & 0.006 & -16.764 & -2.981 & $* * *$ \\
\hline Constant & 30.494 & 17.560 & 1.74 & 0.086 & -4.438 & 65.427 & * \\
\hline
\end{tabular}

Notes: ${ }^{* *}$ - significance at $1 \%$ level, ${ }^{* *}$ - significance at $5 \%$ level, ${ }^{*}$ - significance at $10 \%$ level.

Sources: developed by the author using Stata 12/SE.

Gross fixed capital formation is influenced by the biggest amount of environmental innovation factors: 1 ) an increase in $1 \%$ of electricity production from oil sources boosts gross fixed capital formation by $0.269 \%$; 2) an increase in $1 \%$ employment in industry results in the increase of dependent variable in $0.613 \%$; 3 ) an increase in 1 unit of patent applications from residents results in statistically significant but not scaled increase of gross fixed capital formation.

Table 6. Results of the identification of environmental innovation measures impact on foreign direct investment in 9 countries in 2005-2019 (fixed effects model specification)

\begin{tabular}{lccccccc}
\hline FDI & Coefficients & Standard Error & t-value & p-value & \multicolumn{2}{c}{$95 \%$ Confidence Interval } & Sig \\
\hline CO2 & $10.5 \cdot 10^{8}$ & $11.3 \cdot 10^{8}$ & 0.92 & 0.359 & $-12.1 \cdot 10^{8}$ & $33 \cdot 10^{8}$ & \\
El_oil & $-6.8 \cdot 10^{8}$ & $5.14 \cdot 10^{8}$ & -1.32 & 0.190 & $-17 \cdot 10^{8}$ & $3.43 \cdot 10^{8}$ & \\
Empl & $-32.3 \cdot 10^{8}$ & $21.5 \cdot 10^{8}$ & -1.50 & 0.137 & $-75.1 \cdot 10^{8}$ & $10.5 \cdot 10^{8}$ & \\
Pat_res & $-0.263 \cdot 10^{7}$ & $0.202 \cdot 10^{7}$ & -1.30 & 0.195 & $-0.664 \cdot 10^{7}$ & $0.138 \cdot 10^{7}$ & \\
RD_exp & $15.4 \cdot 10^{9}$ & $9.01 \cdot 10^{9}$ & 1.71 & 0.090 & $-2.48 \cdot 10^{9}$ & $33.4 \cdot 10^{8}$ & $*$ \\
Constant & $54.6 \cdot 10^{9}$ & $4.56 \cdot 10^{9}$ & 1.20 & 0.235 & $-36.2 \cdot 10^{9}$ & $145 \cdot 10^{8}$ & \\
\hline
\end{tabular}

Notes: ${ }^{* * *}$ - significance at $1 \%$ level, ${ }^{* *}$ - significance at $5 \%$ level, ${ }^{*}$ - significance at $10 \%$ level.

Sources: developed by the author using Stata 12/SE.

Table 7. Results of the identification of environmental innovation measures impact on gross fixed capital formation growth in 9 countries in 2005-2019 (fixed effects model specification)

\begin{tabular}{lccccccc}
\hline GFCF & Coefficients & Standard Error & t-value & p-value & 95\% Confidence Interval & Sig \\
\hline CO2 & 0.000 & 0.210 & 0.00 & 1.000 & -0.418 & 0.418 & \\
El_oil & 0.269 & 0.090 & 2.97 & 0.004 & 0.089 & 0.448 & $*$ \\
Empl & 0.613 & 0.383 & 1.60 & 0.100 & -0.148 & 1.374 & $*$ \\
Pat_res & 0.000 & 0.000 & -1.78 & 0.079 & -0.001 & 0.000 & $*$ \\
RD_exp & 1.941 & 1.636 & 1.19 & 0.238 & -1.307 & 5.189 & \\
Constant & 7.209 & 8.410 & 0.86 & 0.393 & -9.485 & 23.903 & \\
\hline
\end{tabular}

Notes: ${ }^{* * *}$ - significance at $1 \%$ level, ${ }^{* *}$ - significance at $5 \%$ level, ${ }^{*}$ - significance at $10 \%$ level.

Sources: developed by the author using Stata 12/SE.

Conclusions. Oil extraction and production nowadays are highly challenged by numerous external factors. The most significant role plays highly increasing competition from the renewable energy industry and the necessity of eliminating negative environmental consequences. Bibliometric analysis of environmental innovation research in Scopus (871 publication) allows underlining several scientific research perspectives. Namely, it is revealed that environmental innovation is closely connected with such 
issues as 1) business strategic development and country sustainable development issues; 2) energy efficiency, renewable energy, and anti-pollution issues; 3) innovative and environmentally-friendly managerial technologies; 4) patenting and knowledge-based approach; 5) recycling issues; 6) energy use issues; 7) environmental expenditures and emission trading. Realization of panel data regression analysis on the identification of the impact of environmental innovation issues on socio-economic development in oil-producing countries allow supporting theoretical conclusions: electricity production from oil sources boosts GDP growth, and gross fixed capital formation, expansion of research and development expenditures has a positive impact on GDP growth, and negative - on current account balance, an increase of patent application from residents has a positive impact on gross fixed capital formation. Therefore, it might be concluded that environmental innovation in oil-producing countries improves the competitiveness of oil enterprises and stimulates socio-economic growth in these countries.

Funding: This research received no external funding.

\section{References}

Berrone, P., Fosfuri, A., Gelabert, L., \& Gomez-Mejia, L. R. (2013). Necessity as the mother of 'green'inventions: Institutional pressures and environmental innovations. Strategic Management Journal, 34(8), 891-909. [Google Scholar] [CrossRef]

Brunnermeier, S. B., \& Cohen, M. A. (2003). Determinants of environmental innovation in US manufacturing industries. Journal of environmental economics and management, 45(2), 278-293. [Google Scholar] [CrossRef]

Cainelli, G., Mazzanti, M., \& Montresor, S. (2012). Environmental innovations, local networks and internationalization. Industry and Innovation, 19(8), 697-734. [Google Scholar] [CrossRef]

De Marchi, V. (2012). Environmental innovation and R\&D cooperation: Empirical evidence from Spanish manufacturing firms. Research policy, 41(3), 614-623. [Google Scholar] [CrossRef]

Donlagic, A., \& Moskalenko, B. A. (2020). The Impact Of FDI Inflow On The Environment: A Case Of The Baltic-Black Sea Region Countries. SocioEconomic Challenges, 4(4), 151-159. [Google Scholar] [CrossRef]

El Amri, A., Boutti, R., Oulfarsi, S., Rodhain, F., \& Bouzahir, B. (2020). Carbon financial markets underlying climate risk management, pricing and forecasting: Fundamental analysis. Financial Markets, Institutions and Risks, 4(4), 31-44. [Google Scholar] [CrossRef]

Geffen, C. A., \& Rothenberg, S. (2000). Suppliers and environmental innovation: the automotive paint process. International Journal of Operations \& Production Management, 20(2), 166-186. [Google Scholar] [CrossRef]

Hall, J. (2000). Environmental supply chain dynamics. Journal of cleaner production, 8(6), 455-471. [Google Scholar] [CrossRef

He, S. (2019). The Impact of Trade on Environmental Quality: A Business Ethics Perspective and Evidence from China. Business Ethics and Leadership, 3(4), 43-48. [Google Scholar] [CrossRef]

Horbach, J. (2008). Determinants of environmental innovation-New evidence from German panel data sources. Research policy, 37(1), 163-173. [Google Scholar] [CrossRef]

IEA. (2020). Global Energy Review 2020: The impacts of the COVID-19 crisis on global energy demand and CO2 emissions Retrieved from [Link]

IEA. (2021). World Energy Outlook special report «The Oil and Gas Industry in Energy Transitions». Retrieved from [Link]

Karintseva, O., \& Benetyte, R. (2018). Estimation of efficiency of state regulation in economic restructuring based on the environmental factor. SocioEconomic challenges (SEC), 2(1), 91-102. [Google Scholar]

Kemp, R., \& Pearson, P. (2007). Final report MEI project about measuring eco-innovation. UM Merit, Maastricht, 10(2). [Google Scholar]

Lanjouw, J. O., \& Mody, A. (1996). Innovation and the international diffusion of environmentally responsive technology. Research Policy, 25(4), 549-571. [Google Scholar] [CrossRef]

Mishenin, Y. V., Yarova, I. Y., Klisinski, J., \& Rak, A. (2020). Ensuring healthy environment: mechanisms of cluster structures development in the field of waste management. Health Economics and Management Review, 1(2), 78-90. [Google Scholar] [CrossRef]

Owen, N., Humpel, N., Leslie, E., Bauman, A., \& Sallis, J. F. (2004). Understanding environmental influences on walking: review and research agenda. American journal of preventive medicine, 27(1), 67-76. [Google Scholar] [CrossRef]

Padel, S. (2001). Conversion to organic farming: a typical example of the diffusion of an innovation?. Sociologia ruralis, 41(1), 40-61. [Google Scholar] [CrossRef]

Rennings, K., Ziegler, A., Ankele, K., \& Hoffmann, E. (2006). The influence of different EU environmental management and auditing schemes on technical environmental innovations and economic performance. Ecological Economics, 57(1), 45-59. [Google Scholar] [CrossRef] 
Scopus (2021). Retrieved from [Link]

Taliento, M., \& Netti, A. (2020). Corporate Social/Environmental Responsibility and Value Creation: Reflections on a Modern Business Management Paradigm. Business Ethics and Leadership, 4(4), 123-131. [Google Scholar] [CrossRef]

Vasylieva, T., Lyeonov, S., Lyulyov, O., \& Kyrychenko, K. (2018). Macroeconomic stability and its impact on the economic growth of the country. Montenegrin Journal of Economics, 14(1), 159-170. [Google Scholar] [Google Scholar]

VOSviewer. (2021). Retrived from [Link]

World Bank. (2021) Retrieved from [Link]

Аріф Г. Гусейнов, д.е.н., професор, Азербайджанський державний університет нафти і промисловості, Азербайджан Екологічні інновації: вплив на соціально-економічний розвиток держави

Глобальне потепління та погіршення екологічної ситуації потребують розробки та впровадження інновацій, спрямованих на зменшення негативного впливу промисловості на навколишнє природне середовище. Вважається, що нафтова промисловість є однією з найбільш екологічно забруднювальних галузей. Таким чином, впровадження екологічних інновацій у нафтовій галузі $€$ актуальним. Метою статті $€$ визначення впливу екологічних інновацій на параметри соціальноекономічного розвитку в країнах, що спеціалізуються на видобутку нафти. У статті здійснено бібліометричний аналіз за допомогою інструментарію програмного забезпечення VOSviewer v.1.6.16. Отримані результати дозволили виявити ключові контекстні напрямки наукових досліджень щодо важливості екологічних інновацій. У роботі висунуто та перевірено наукову гіпотезу про позитивний вплив екологічних інновацій на соціально-економічний розвиток країни. У роботі, вимірниками екологічних інновацій обрано викиди СО2 від обробної промисловості та будівництва, виробництво електроенергії 3 нафти, зайнятість у промисловості та додана вартість промисловості, тоді як індикаторами оцінювання соціально-економічного розвитку країни - зростання ВВП, сальдо рахунку поточних операцій, прямі іноземні інвестиції та валове формування основного капіталу. Перевірка висунутої гіпотези передбачає реалізацію кількох завдань, а саме: 1) кореляційний аналіз, спрямований на виявлення пояснювальних змінних, між якими є сильна кореляція, та їх елімінування для уникнення проблеми мультиколінеарності; 2) комплексний аналіз описової статистики, спрямований на виявлення адекватності масиву даних; 3) ідентифікація специфікації моделі за допомогою тесту Хаусмана (модель з випадковими чи фіксованими ефектами); 4) регресійне моделювання та характеристика його результатів. Практична реалізація дослідження була здійснена з використання програмного забезпечення Stata 12/SE. Емпіричне дослідження проведено на основі панельних даних, сформованих для вибірки з 9 країн, які спеціалізуються на видобутку нафти (Азербайджан, Канада, Бразилія Російська Федерація, Саудівська Аравія, Оман, Румунія, Республіка Ємен та Ісламська Республіка Іран). Періодом дослідження обрано 2005-2019 роки. За результатами бібліометричного та панельно-регресійного аналізу зроблено висновок про те, що екологічні інновації в країнах, які спеціалізуються на видобутку та обробці нафти, дозволяють не тільки підвищити конкурентоспроможність підприємств нафтової індустрії, але й стимулювати соціально-економічне зростання в цих країнах.

Ключові слова: екологічні інновації, соціально-економічний розвиток, нафтова промисловість, панельний аналіз даних. 